\title{
THE PREPARATION AND UTILIZATION OF THE CATIONIC SORBENT BASED ON THE SURFACTANT MODIFIED BOTTLE GOURD SHELL
}

Dragana Z. Marković-Nikolić ${ }^{2}$, $^{*}$, Aleksandar Lj. Bojić ${ }^{2}$, Goran Petković ${ }^{1}$, Nebojša Ristić ${ }^{1}$, Milorad D. Cakić ${ }^{3}$, Goran S. Nikolić ${ }^{3}$

(ORIGINAL SCIENTIFIC PAPER) UDC 582.681.71:661.185:66.081

\footnotetext{
${ }^{1}$ High Technologically Artistic Professional School, Leskovac, Serbia

2Department of Chemistry, Faculty of Sciences and Mathematics, University of Niš, Niš, Serbia

${ }^{3}$ Faculty of Technology, University of Niš, Leskovac, Serbia
}

The surface of the bottle gourd shell (BGS), a solid agricultural residue of Lagenaria vulgaris Ser. was chemically modified using a cationic surfactant, hexadecyltrimethylammonium chloride (HTAC). The success of the modification was confirmed by FTIR spectroscopy. Chemical characterization of the lignocellulosic BGS biomass and the surfactant modified bottle gourd shell (MBGS) was carried out using the compositional and elemental analysis. The amount of surfactant sorbed on the BGS surface was measured as a function of the surfactant bulk concentration. Sorption isotherms were used to verify self-assembly models of cationic surfactant sorption onto oppositely charged MBGS substrates. The shape of sorption isotherms was applied to describe the behavior of the surfactant/BGS system. The surfactant modified shell was tested as a sorbent for the removal of phosphate and nitrate from contaminated aqueous solutions. The sorption of anionic pollutants on MBGS was performed in a series of batch sorption experiments at $20^{\circ} \mathrm{C}$. It was found that the MBGS yielded sorption efficiency was $40 \%$ for phosphate and $22 \%$ for nitrate. The sorption mechanism involving the ion exchange might be responsible for the uptake of anions. The morphology and surface properties of the MBGS sorbent before and after sorption of anionic pollutants were analyzed by SEM methods. Compared to other non-surfactant sorbents, the advantage of MBGS as a sorbent is that it can be used for the removal of anionic pollutants not only from aqueous solutions but also from the emulsified oil wastewater or nonpolar effluents.
Keywords: bottle gourd shell, cationic surfactant, sorption, anionic pollutants, wastewater treatment

\section{Introduction}

Agricultural residues, as well as industrial waste biomasses, are important for various practical applications, especially in the field of the wastewater treatment. Increasing the interest in natural, renewable, and biodegradable materials makes the agricultural residues like lignocellulosic polymers attractive raw materials for the preparation of pollutant sorbents [1]. Various covalent and non-covalent modification approaches have been developed for lignocellulosic materials to make functional particles or to improve their dispersion in hydrophobic polymer matrices, such as radical and graft polymerizations [2]. Alternatively, surface modification of waste biomass can be made via sorption of surfactants, which is considered a noncovalent surface modification. A surfactant is defined as a material that can greatly reduce the surface tension of water when used in very low concentrations [3]. The surfactant-based lignocellulosic biomasses have drawn much attention lately because they present many novel performances such as low cost, biodegradation, associative properties in water, rheological properties, and surface-active properties that can control sorption of different ionic pollutants.
Surface modifications of waste biomass through the interaction with different cationic surfactants, as well as their applications for the removal of anionic pollutants from aqueous solutions, have been the subject to intensive studies, especially during the last decade $[4,5]$. In this sense, the following cationic surfactants are mainly used: octadecyltrimethylammonium bromide (C18, OTAB), cetyltrimethylammonium bromide (C16, CTAB) or chloride (C16, CTAC), cetylpyridinium bromide (C16, CPB) or chloride (C16, CPC), tetradecyltrimethylammonium bromide (C14, TTAB) and dodecylpyridinium chloride (C12, DPC) [6]. For the purpose of making sorbents, modifications of many biomasses or other substrates were carried out as follows: cellulose fibers with CTAB [7], wheat straw with CPB to remove anionic dyes [8], the tea waste with $\mathrm{CTAB}$ and $\mathrm{CPB}$ for the removal of anionic congo-red [9], silkworm exuviae with CTAB for removing anionic methyl orange [10], yeast biomass and lichens with CTAB to remove chromates [11], barley straw with $\mathrm{CPC}$ for the removal of food and mineral oils [12], coir pith with CTAB for the removal of chromates, sulphates and thiocyanates $[13,14]$, zeolite with CTAB to

\footnotetext{
* Author address: Dragana Z. Marković-Nikolić, High Technologically Artistic Professional School, Vilema Pušmana 17, 16000 Leskovac, Serbia

E-mail: dragana.markovic2812@gmail.com

The manuscript received: September, 8, 2017.

Paper accepted: October, 19, 2017.
} 
remove phosphate [15], acetate-cellulose membranes with TTAB, CTAB, CTAC, and CPC for the removal of nitrates [16].

Taking into account these studies, it is obvious that the biomass of the bottle gourd shell (BGS) has not been the subject of surfactant-based modification so far. Also, the surface modified biomass has not been studied as a sorbent to remove phosphate and nitrate from aqueous solutions. The bottle gourd (genus Lagenaria), one of the first cultivated plants in the world, is a genus of gourd-bearing vines in the squash family (Cucurbitaceae). The bestknown species Lagenaria siceraria (synonym Lagenaria vulgaris Ser.) is a cultivated plant grown for its fruit [17]. The fruit can be harvested young and used as a vegetable. The fresh fruit has a light-green smooth shell and a white flesh. The fruit pulp has been known for its healing properties, and has been utilized for the treatment of various ailments since ancient times [18]. More often, the bottle gourd is collected mature, then dried, and exploited in making utensils, musical instruments, pipes, bottles, or water containers (Figure 1). As the main structural components of the plant cell wall, the fresh fruit shell contains crude protein (15-18\%), cellulose (18-20\%) and lignin (8-10\%) [19]. However, the dried shell is a hard material with the lignocellulosis structure. Depending on the origin and storage conditions, the dried bottle gourd shell (BGS) mainly contains polysaccharides (cellulose $35-40 \%$, hemicellulose $15-20 \%$ ) and lignin $35-40 \%$ [20-22]. The availability of specific functional groups such as hydroxyl $(\mathrm{OH})$ existing in the cellulose, hemicelluloses, as well as the lignin structure suggests a potential of using BGS as a sorbent material. In the past, BGS has been selected to be a sorbent for the removal of heavy metals from wastewater [20,23-25].

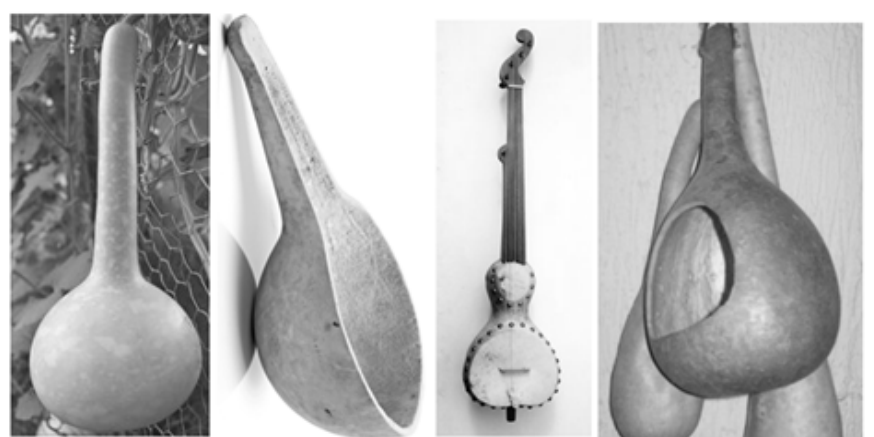

Figure 1. The fresh and dried fruit of the bottle gourd (Lagenaria vulgaris)

The BGS biomass is of a hydrophilic nature, as is the case for cellulose itself. This causes difficulties in mixing BGS with hydrophobic effluents, and therefore its utilization has been limited. Broadening its field of application would require developing different degrees of surface hydrophobicity [26]. The porous BGS has a high surface area to volume ratio, which means that it has a highly reactive and easy to functionalize surface [25]. As is the case with all lignocellulosic biomasses and their derivatives, hydroxyl groups are the primary reactive sites for the surface modification. BGS possess negative charges on its surface at neutral $\mathrm{pH}$, due to the presence of $\mathrm{OH}$ (from cellulose and lignin constituents) and $\mathrm{COOH}$ (from hemicelluloses) groups, which improves their stability in aqueous solutions, but restricts its dispersibility in most non-polar solvents. Therefore, a cationic surfactant was investigated to modify the BGS surface in this study. Cationic surfactants, such as quaternary ammonium compounds, have been employed in the past to exchange the extra structural cations of clays, enhancing the surface affinity for organic species such as nonionic organic compounds [27] and hydrophobic organic compounds [28]. Quaternary ammonium salts have also been used to modify cellulose surfaces [29]. Furthermore, the use of surfactant treated materials to remove oil-in-water has been investigated such as wheat straw and organoclay [30]. Chemical functionalization of the biomass surface by a cationic surfactant is carried out to introduce stable positive electrostatic charges on the surface to obtain better dispersion, and tune its surface energy characteristics to improve compatibility, especially when used in conjunction with nonpolar or hydrophobic materials [31]. However, one of disadvantages of using surfactants for the surface modification of biomass is that large volumes are required due to a high specific area [32]. In this regard, the development of the method for surface modification of biomass was carried out by the addition of a reduced amount of cationic surfactant.

The main objective of this research was to modify the surface of the BGS biomass by using a cationic surfactant. This is possible since the BGS surface is covered with a large amount of charged anionic sites at neutral $\mathrm{pH}$. For this research, hexadecyltrimethylammonium chloride (HTAC) was selected and used as a quaternary ammonium reagent. $\mathrm{HTAC}\left(\mathrm{C}_{19} \mathrm{H}_{42} \mathrm{NCl}, 320 \mathrm{~g} \mathrm{~mol}^{-1}\right)$ is a tetra-substituted ammonium cationic surfactant with permanently charged quaternary nitrogen, and a long straight alkyl (C16) chain that imparts it with a high degree of hydrophobicity (Figure 2). HTAC has some advantages over other materials used so far to modify the surface of lignocellulosic biomasses. The surfactant is water soluble (dispersible), stable in both acid and alkali media, and exhibits a strong cationic activity. It exists as a monomer at the concentration below the critical micelle concentration (CMC of about $1.3 \mathrm{mmol} \mathrm{dm}^{-3}$ ) or as micelles at the concentration above CMC. Around that, HTAC is readily available, inexpensive and can be degraded by microorganisms [33]. Although different modification methods have been developed for biomass, little attention has been paid to controlling the degree of hydrophobicity of the resulted product. Because of that, the modification was conducted under different surfactant concentrations so as to impose different degrees of hydrophobicity. Controlling the hydrophobicity of the BGS biomass is very important to achieve the best compatibility between the MBGS product and anionic contaminated effluents. The HTAC interaction with the BGS biomass has been studied to evaluate the potential use of MBGS as a sorbent for anionic pollutants in the environmental technology. 


\section{Experimental}

\section{Reagents and materials}

All reagents used in the experiments were of analytical grade. Inorganic reagents such as $\mathrm{HCl}, \mathrm{NaOH}, \mathrm{KNO}_{3}$ and $\mathrm{KH}_{2} \mathrm{PO}_{4}$ were purchased from Merck (Germany). The organic surfactant, hexadecyltrimethylammonium chloride (HTAC) (solution of 25 wt. \% in $\mathrm{H}_{2} \mathrm{O}$, density of $0.968 \mathrm{~g} \mathrm{~cm}^{-3}$ at $25{ }^{\circ} \mathrm{C}$ ), was obtained from SigmaAldrich (Chemie, $\mathrm{GmbH}$ ) and used for the modification process in this study. The molecular structure of HTAC is illustrated in Figure 2. All solutions were prepared with deionized water (18 $\mathrm{M} \Omega$ ). Working standard solutions of phosphate $\left(10 \mathrm{mg} \mathrm{P} \mathrm{dm}^{-3}\right)$ and nitrate $\left(10 \mathrm{mg} \mathrm{N} \mathrm{dm}^{-3}\right)$ anions were prepared just before use by the appropriate dilution of the stock solutions $\left(100 \mathrm{mg} \mathrm{dm}^{-3}\right)$. All standard solutions were stored in a refrigerator at $+4{ }^{\circ} \mathrm{C}$.

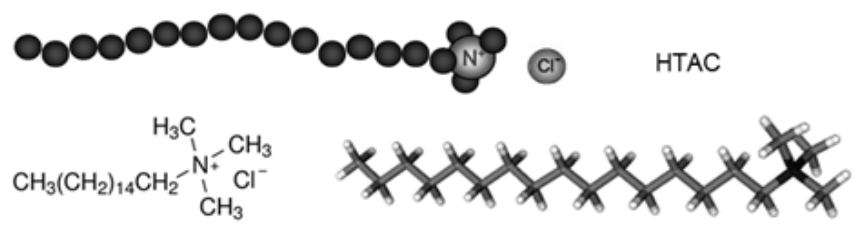

Figure 2. The molecular structure of hexadecyltrimethylammonium chloride $\left(\mathrm{C}_{19} \mathrm{H}_{42} \mathrm{NCl}\right)$ and $3 \mathrm{D}$ model of the cationic HTAC surfactant

The bottle gourd shell (BGS), grown in the southern area of Serbia (near Leskovac) without irrigation and fertilization, at an altitude of $280 \mathrm{~m}$, was used as the starting material in this experiment. In that sense, the naturally dried shell of Lagenaria vulgaris was manually emptied and crushed into 1 to $2 \mathrm{~cm}$ pieces. The raw biomass was soaked and washed with deionized water to remove dust and soluble impurities. The washed material was dried in an oven for $24 \mathrm{~h}$ at $60^{\circ} \mathrm{C}$ to achieve its constant weight. Then, the residual material was milled in a crusher mill (Waring 8010 ES, Germany) and sieved to separate a size between 500 and $800 \mu \mathrm{m}$ using successive sieving through octagon sieves (Oct-Digital 4527-01).

\section{Characterization methods}

The constituents and physical properties of BGS were determined according to the standard Association of Official Analytical Chemists (AOAC) procedures. The modification of the BGS biomass by the cationic surfactant was confirmed by the elemental (CHNS/O) analysis, using a Elemental Analyzer (Vario EL III CHNS/O system $\mathrm{GmbH}$ ) to assess add functional groups. Fourier transform infrared spectra of the samples were recorded in the wavenumber range of $4000-400 \mathrm{~cm}^{-1}$, using an FTIR Spectrophotometer (BOMEM MB-100, Hartmann \& Braun, Canada) operating at the resolution of $2 \mathrm{~cm}^{-1}$ and 16 scans. The samples were compressed in a potassium bromide $(\mathrm{KBr})$ pellet prior to spectroscopy. The FTIR spectra were analyzed using Win Bomem Easy software, in order to identify the surface functional groups present on the BGS biomass and the MBGS sorbent.
The surface morphology of the samples, before and after anions loading, was studied using scanning electron microscope (SEM) images which were taken by a JEOL JSM-6610LV microscope. The samples were coated with chrome, under vacuum in an argon atmosphere, before observation of SEM. An accelerating voltage of $20 \mathrm{keV}$ for primary electrons, as well as the working distance of $10 \mathrm{~mm}$ proved to be satisfactory. Spot sizes varied depending on the applied magnification.

Preparation of the surfactant modified sorbents

Prior to the treatment with HTAC, the raw BGS biomass was treated with $5 \mathrm{M} \mathrm{NaOH}$ solution $(\mathrm{pH} 10)$. The suspension was shaken by an orbital shaker at the speed of $150 \mathrm{rpm}$ at $80{ }^{\circ} \mathrm{C}$ for $30 \mathrm{~min}$. The alkali-treated BGS was rinsed with deionized water and dried in an oven at about $60{ }^{\circ} \mathrm{C}$ for $10 \mathrm{~h}$. The surfactant modified sorbent (MBGS) was prepared by soaking the BGS biomass $(1 \mathrm{~g})$ in $500 \mathrm{~cm}^{3}$ of the HTAC solution of the desired concentration $\left(1.15\right.$ and $\left.2.56 \mathrm{mmol} \mathrm{dm}^{-3}\right)$. The suspension was then stirred on a magnetic stirrer (at $150 \mathrm{rpm}$ ) for $8 \mathrm{~h}$ at $25^{\circ} \mathrm{C}$. The solid phase was filtered and washed with deionized water several times to remove the surface retained surfactant, and until no $\mathrm{Cl}^{-}$was detected by $\mathrm{AgNO}_{3}$ solution. Finally, the sample was dried in an oven at $60^{\circ} \mathrm{C}$ for $10 \mathrm{~h}$ (to constant weight). The prepared products were stored in an airtight glass container and labeled as MBGS1 sorbent (lower concentrations, below $\mathrm{CMC}$ ) and MBGS2 sorbent (higher concentration, above CMC).

\section{Sorption isotherms of surfactant}

The sorption isotherms of the cationic surfactant were carried out at $25{ }^{\circ} \mathrm{C}$ using the depletion method [6]. The appropriate volume of the high-concentration HTAC stock solution ( 25 wt. $\%$ in $\mathrm{H}_{2} \mathrm{O}$ ) was added to the $1 \%$ BGS suspension to obtain surfactant concentrations ranging from 0.01 to $2.60 \mathrm{mmol} \mathrm{dm}^{-3}$. The $\mathrm{pH}$ of the suspension was not affected by the addition of cationic HTAC, and the pH was close to 6.8 for all samples. The suspension was then stirred for $10 \mathrm{~h}$ at $25^{\circ} \mathrm{C}$ to reach sorption equilibrium. Dispersions were then centrifuged at $1500 \mathrm{rpm}$ for $10 \mathrm{~min}$, and the amount of the free surfactant in the supernatant was determined by UV absorption at $260 \mathrm{~nm}$ (Varian CARY 100 Conc. UV-VIS Spectrophotometer).

\section{Batch sorption studies of anionic pollutants}

Sorption experiments were evaluated in the batch equilibrium mode. All experiments were conducted by mixing $50 \mathrm{~cm}^{3}$ of phosphate $\left(10 \mathrm{mg} \mathrm{P} \mathrm{dm}^{-3}\right)$ or nitrate (10 $\mathrm{mg} \mathrm{N} \mathrm{dm}{ }^{-3}$ ) working solution with $2 \mathrm{~g} \mathrm{dm}^{-3}$ of the desired sorbent (MBGS1 or MBGS2). The $\mathrm{pH}$ values of the initial solutions were adjusted to $6.8 \pm 0.1$ with dilute $\mathrm{HCl}(0.1 \mathrm{M})$ or $\mathrm{NaOH}(0.1 \mathrm{M})$ solution. The mixtures were stirred at $150 \mathrm{rpm}$ in order to ensure a good mixing without the vortex effect. The temperature was maintained at $20 \pm$ $1{ }^{\circ} \mathrm{C}$ using a temperature-controlled water bath. After 
the equilibrium time was completed (60 $\mathrm{min})$, the suspensions were centrifuged at $1500 \mathrm{rpm}$ for $10 \mathrm{~min}$. The phosphate aliquots were analyzed for the residual phosphate concentration (expressed over $\mathrm{P}-\mathrm{PO}_{4}$ ), axially at $213.618 \mathrm{~nm}$ by inductively coupled plasma-optical emission spectrometry (ICP-OES) on an instrument ARCOS FHE12 (Spectro, Germany), according to the manufacturer's instructions. The nitrate aliquots were analyzed for the residual nitrate concentration (expressed over $\mathrm{N}-\mathrm{NO}_{3}$ ), at $220 / 275 \mathrm{~nm}$ by an UV-VIS spectrophotometer (Cary-100 Conc., Varian), according to the Standard $4500-\mathrm{NO}_{3}$ methods [34]. The equilibrium sorption capacities of MBGS sorbents were calculated using the following equation:

$Q_{e}=\frac{\left(C_{0}-C_{e}\right) V}{m}$

where: $\mathrm{Qe}\left(\mathrm{mg} \mathrm{g}^{-1}\right)$ is the amount of $\mathrm{P}-\mathrm{PO}_{4}$ or $\mathrm{N}-\mathrm{NO}_{3}$ sorption per gram sorbent at equilibrium; $\mathrm{Co}$ and $\mathrm{Ce}\left(\mathrm{mg} \mathrm{dm}^{-3}\right)$ are the concentrations of $\mathrm{P}-\mathrm{PO}_{4}$ or $\mathrm{N}-\mathrm{NO}_{3}$ at original and equilibrium, respectively; $\mathrm{V}\left(\mathrm{dm}^{-3}\right)$ is the volume of the solution, and $m(\mathrm{~g})$ is the dry mass of the sorbent. Following the experiments, the post-sorption sorbent samples were collected for further characterizations.

\section{Results and discussion}

The main challenge for the chemical functionalization of BGS is to conduct the process in such a way that it only changes its surface, while preserving its original morphology so as to avoid any polymorphic conversion and maintain the integrity and mechanical properties of the material. Another challenge in modifying BGS is to design a simple modification system with no or minimum negative impact on the environment. In this sense, the chemical composition of the BGS biomass was first analyzed, according to which the method of modifying its surface with the HTAC surfactant was designed.

Chemical composition and biomass properties

The natural BGS biomass is subjected to the investigation of biochemical and physical properties, according to standard AOAC procedures (Table 1). All values are means of triplicate determinations and expressed in percent (\%) based on the dry weight. The biochemical analysis has shown that lignin is the most represented component in the biomass. A high proportion of holocellulose (cellulose and hemicellulose) in BGS suggests more hydroxyl groups available in the modification process. The protein content is extremely low, while the volatile matters were not detected considering that the BGS is natural dried. The plant material was generally low in ash, consisting mainly metals (such as $\mathrm{Zn}, \mathrm{Cu}$ and $\mathrm{Mn}$ ) bio-accumulated in the plant during growth [20].

These data are in accordance with characteristics of other plants from the genus Lagenaria [35]. The comparative analysis of the chemical composition of different agricultural waste, tested for anion sorption (pecan shells, peanut shells, almond shells, cotton seed hulls, rice hulls, sugarcane bagasse, corn cob, corn stover, oat hulls, oak chips, rice straw, soybean hulls), shows that BGS is most similar to almond, peanut and pecan shells, considering a high lignin content (between 27 and 48\%), and the similar content of other constituents [36]. However, one should bear in mind the fact that even the same biomass, but of different natural origin and sites have a very different composition (e.g. rice and sugarcane bagasse), which will certainly affect their modification and a different yield, and therefore the anion sorption and their mechanism [37].

Table 1. Biochemical and physical properties of the raw BGS biomass

\begin{tabular}{llll}
\hline Component & Content & Parameter & Value \\
\hline \multicolumn{1}{c}{ Biochemical properties } & & \multicolumn{2}{c}{ Physical properties } \\
\hline Lignin & $41.90 \pm 0.51 \%$ & Ash & $0.28 \pm 0.04 \%$ \\
Cellulose & $39.60 \pm 0.42 \%$ & Moisture & $3.80 \pm 0.14 \%$ \\
Hemicellulose & $18.20 \pm 0.14 \%$ & bulk density & $0.46 \pm 0.07 \mathrm{~g} \mathrm{~cm}^{-3}$ \\
Protein & $<0.1 \%$ & bulk weight & $103.03 \pm 0.87 \mathrm{~kg} \mathrm{~m}^{-3}$ \\
\hline
\end{tabular}

Design of the BGS surface modification method

Taking into account the previous experience of the practical application of the surfactant-cellulosic sorbent for the removal of anions (such as nitrate and phosphate) from wastewater $[15,16]$, the properties of the starting agricultural biomass, and the fact that chlorides in the previous sorbents had the role of a counterion, hexadecyltrimethylammonium chloride (HTAC) was selected as the optimum cationic surfactant for the BGS modification in this study. Prior to the treatment with HTAC, the BGS biomass was treated with an aqueous sodium hydroxide (5M) to enhance the sorption capability for HTAC. The alkaline hydrolyzation of lignocellulosic material increasing the formation of hydroxyl and carboxyl groups which are responsible for binding activities [38]. Considering the critical micellar concentration (CMC) of this surfactant $\left(1.28 \mathrm{mmol} \mathrm{dm}^{-3}\right.$, determined by a surface tension at $25{ }^{\circ} \mathrm{C}$ ), in accordance with the aforementioned literature data $[4,5]$, two different concentrations of the solution were used for the BGS modification process: below CMC $(0.9 \times \mathrm{CMC})$ and in excess $(2.0 \times \mathrm{CMC})$, i.e. 1.15 and $2.56 \mathrm{mmol} \mathrm{dm}^{-3}$, respectively. Prepared sorbents of MBGS1 (lower concentration, for $0.58 \mathrm{mmol} \mathrm{g}^{-1}$ ) and MBGS2 (higher concentration, for $1.28 \mathrm{mmol} \mathrm{g}^{-1}$ ) were characterized and used to test the efficiency of anions sorption (phosphate and nitrate) from the aqueous solution.

Physicochemical characterization of MBGS sorbents

In order to confirm the introduction of quaternary cationic groups into the structure of the BGS biomass, the obtained sorbents have been characterized by physicochemical methods such as the elemental analy- 
sis and the reaction efficiency. The elemental analysis (CHNS/O) was used to estimate additional functional groups in sorbents during the BGS biomass modification process. Changes in the type and the elements content of the initial BGS biomass and the resulting MBGS sorbents are shown in Table 2. The presence of sulfur has not been identified in the samples tested. Other characteristic parameters, such as the reaction efficiency (RE), a degree of substitution (DS), the amount of added cationic groups (Nadd) and the product yield ( $P Y)$ are determined in the function of the nitrogen content $(\mathrm{N})$ :

$\operatorname{Nadd}\left(\mathrm{mmol} \mathrm{N} \mathrm{g}{ }^{-1}\right)=\left(\mathrm{Ns}_{\mathrm{s}}-\mathrm{N}_{\mathrm{B}}\right) \cdot 0.714$

$\mathrm{DS}=162 \cdot \mathrm{Ns}_{\mathrm{s}} /(14 \cdot 100-M \cdot \mathrm{Ns})$.

$\operatorname{RE}(\%)=($ Nadd $/ \mathrm{Q}) \cdot 100$

$\mathrm{PY}(\%)=(m s / m B) \cdot 100$

where $\mathrm{N}_{\mathrm{s}}$ and $\mathrm{N}_{\mathrm{B}}$ are the nitrogen content (\%) in sorbent and biomass (estimated from the elemental analysis); factor 0.714 converts units ( $\% \mathrm{~N}$ to $\left.\mathrm{mmol} \mathrm{N} \mathrm{g}^{-1}\right) ; \mathrm{Q}$ is the amount (mmol) of the cationic HTAC agent added to the reaction mixture per gram of the BGS biomass; $M$ is the molecular weight of the cationic HTAC agent ( $\left.\mathrm{g} \mathrm{mol}^{-1}\right)$; 162 is the molecular weight of the anhydrous glucose unit; 14 is the atomic mass of nitrogen; $m s$ and $m B$ are the masses $(\mathrm{g}$ ) of the dry sorbent and biomass samples.

Table 2. Elemental analysis and reaction efficiency of MBGS sorbents

\begin{tabular}{|c|c|c|c|c|c|c|c|c|}
\hline \multirow{2}{*}{ Sample } & \multicolumn{4}{|c|}{ Element (\%) } & \multirow{2}{*}{ 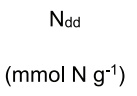 } & \multirow{2}{*}{$\begin{array}{l}\mathrm{RE} \\
(\%)\end{array}$} & \multirow{2}{*}{ DS } & \multirow{2}{*}{$\begin{array}{r}\text { Yield } \\
(\%)\end{array}$} \\
\hline & C & $\mathrm{H}$ & O & $\mathrm{N}$ & & & & \\
\hline BGS biomass & 45.46 & 5.98 & 48.55 & 0.01 & - & - & - & - \\
\hline MBGS1 sorbent & 52.33 & 6.67 & 40.20 & 0.79 & 0.56 & 97.39 & 0.11 & 97.4 \\
\hline MBGS2 sorbent & 60.09 & 6.95 & 31.52 & 1.43 & 1.01 & 78.91 & 0.25 & 97.9 \\
\hline
\end{tabular}

Based on the elemental analysis (Table 2), the values of the $\mathrm{CHO}$ content in the $\mathrm{BGS}$ biomass $(\mathrm{H} / \mathrm{C}$ ratio 0.13$)$ are very similar to the results of the elemental $\mathrm{CHO}$ analysis of other studies, which report the content in various agricultural wastes from $42-59 \%$ for $\mathrm{C}, 3-7 \%$ for $\mathrm{H}$ and $32-50 \%$ for $O[20,36]$. As expected, the unmodified BGS had no nitrogen in its compositions. Significant changes in the nitrogen content were observed in both samples of sorbents, which confirms the effectiveness of biomass modification. The increase in the $\mathrm{N}$ content was here proportional to the concentration of the used solutions, so that almost twice higher content of $\mathrm{N}(1.43 \%)$ was registered with the MBGS2 sorbent as a result of the use of the concentrated solution of the HTAC agent (above $\mathrm{CMC}$ ). This fact indicates a possible mechanism of twolayer aggregation of surfactants on the biomass surface. Based on the amount of added cationic groups in the MBGS sorbent, the theoretical ion exchange capacity of
$1.01 \mathrm{mEq} \mathrm{g}^{-1}$ was calculated by using the Equation 2.

The high values of the reaction efficiency and the product yield indicate the maximum utilization of the used HTAC agent. However, a small degree of substitution and the predicted two-layer mechanism suggest that the obtained data cannot be relevant for assessing the efficacy of the anionic species sorption from the solution. This may be understandable if one takes into account the fact that at least half of the surfactant total amount is occupied by interaction with the biomass active centers, while the rest is available for the sorption process of anionic contaminants. Accordingly, a more realistic exchange capacity of $0.56 \mathrm{mEq} \mathrm{g}^{-1}$ typical for the MBGS1 sorbent should be expected.

\section{FTIR structural characterization}

The Fourier transformation infrared spectroscopy (FTIR) is a rapid analytical technique ideal for the initial classification of organic residues into groups with broadly comparable chemical composition [39-41]. Therefore, FTIR spectroscopy was chosen to characterize all solid samples obtained from the treatment processes. The FTIR spectra of starting the BGS biomass (a), MBGS1 sorbent (b), MBGS2 sorbent (c) and HTAC surfactant (d) are given in Figure 3. The main chemical bond vibrations of the lignocellulosic BGS biomass are detected in the IR region of $2000-400 \mathrm{~cm}^{-1}$ (Figure 3a). Accordingly, this region was selected for the analysis of all samples considered in this study. Absorption bands at 1376, 1161, 1107, 1036 and $897 \mathrm{~cm}^{-1}$ are attributed to carbohydrates in native BGS. The band at $1376 \mathrm{~cm}^{-1}$ corresponds to the bending of $\mathrm{C}-\mathrm{H}$ group in cellulose. The $\mathrm{C}-\mathrm{O}$ asymmetric band was observed at $1161 \mathrm{~cm}^{-1}$. The band at $897 \mathrm{~cm}^{-1}$ corresponds to the vibration of $\beta$-glycosidic $\mathrm{C}-\mathrm{H}$ deformation with a ring vibration contribution characteristic of glycosidic bonds in carbohydrates. The characteristic bands of lignin visible in the BGS spectrum are at 1510, 1458 and $1424 \mathrm{~cm}^{-1}$ and are associated with aromatic skeletal vibrations. Bands at 1510 and $1458 \mathrm{~cm}^{-1}$ are assigned to $\mathrm{C}=\mathrm{C}$ stretching vibration and $\mathrm{C}-\mathrm{H}$ deformations $(\mathrm{CH}$ and $\mathrm{CH}_{2}$ ) in phenol rings, respectively. The symmetric bending vibrations of $\mathrm{C}-\mathrm{H}$ bonds in methoxyl groups of syringyl and guaiacyl units correspond to the $1424 \mathrm{~cm}^{-1}$ band. An absorption vibration is observed at $840 \mathrm{~cm}^{-1}$ that corresponds to out-of-plane deformation vibrations of $\mathrm{C}-\mathrm{H}$ bond of predominantly syringyl units. Apart from this, the strong absorption at $1260 \mathrm{~cm}^{-1}$ is originated by the C-O stretching of acetyl groups present in hemicellulose molecular chains. The vibration band at $1738 \mathrm{~cm}^{-1}$ was assigned to ester-linked acetyl, feruloyl and p-coumaroyl groups between hemicellulose and lignin. The band at $1640 \mathrm{~cm}^{-1}$ was associated with water molecules (crystal hydrates) present in the sample. Moreover, bands at 2925, 2892 and $2850 \mathrm{~cm}^{-1}$ are attributed to asymmetric and symmetric $\mathrm{C}-\mathrm{H}$ stretching of $\mathrm{CH}, \mathrm{CH}_{2}$ and $\mathrm{CH}_{3}$ groups. A broad absorption band around $3430 \mathrm{~cm}^{-1}$ may be attributed to the stretching vibration of $\mathrm{O}-\mathrm{H}$ group in aliphatic (cellulose) and phenolic (lignin) structures. In 
addition, this asymmetrical band evidenced the presence of hydrogen-bond in the BGS biomass structure.

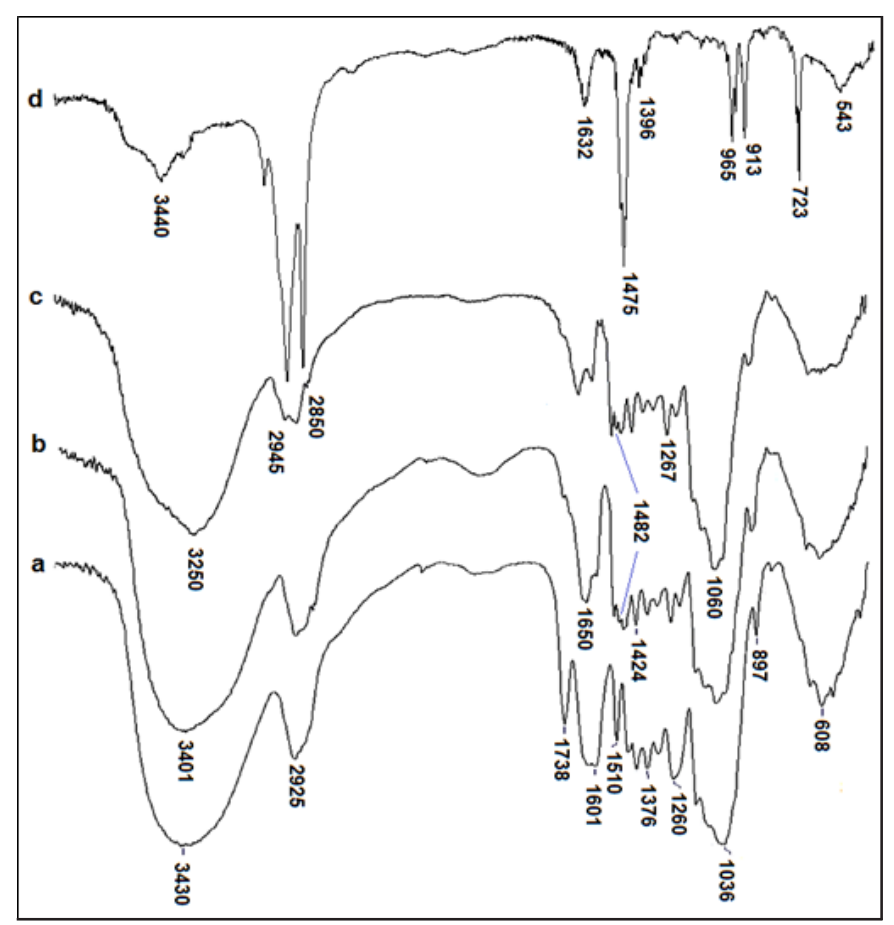

Figure 3. FTIR absorbance spectra of the BGS biomass (a), surfactant modified MBGS1 (b), surfactant modified MBGS2 (c), and HTAC surfactant (d)

From Figure 3b-c it can be noticed that the modification of the BGS biomass by using HTAC surfactant induces some changes of several IR bands. The surfactant modified MBGS1 material is essentially composed of carbohydrates due to the lignin and hemicelluloses extraction in the alkali-treated process (Figure 3b). The bands at 1376 and $1161 \mathrm{~cm}^{-1}$ can be observed in the IR spectrum of this sample, and the appearance of new bands at 1060, 1025 and $996 \mathrm{~cm}^{-1}$, characteristic of carbohydrates, was detected. The absorption peak at $1060 \mathrm{~cm}^{-1}$ is an effect of the C$\mathrm{O}-\mathrm{C}$ ether linkage of the skeletal vibration of both pentose and hexose unit contribution from hemicellulose and cellulose. The peak at $1025 \mathrm{~cm}^{-1}$ is attributed to hemicellulose absorptions explicitly to $\mathrm{C}-\mathrm{O}$ stretching in $\mathrm{C}-\mathrm{O}-\mathrm{C}$ linkages. Arabinosyl side chains are represented by the absorption peak at $996 \mathrm{~cm}^{-1}$. The absorbance of the lignin bands at $1597,1508,1458$ and $1420 \mathrm{~cm}^{-1}$ showed a slight decrease demonstrating a lower lignin content regarding the original content in the native BGS biomass. The vibration band at $1738 \mathrm{~cm}^{-1}$, assigned to ester-linked acetyl groups was not observed in this sample, indicating the successful cleavage of ester linkages between hemicelluloses and lignin in the pre-treatment process. Cellulose characteristic bands in the region of $1250-850 \mathrm{~cm}^{-1}$, such as 1157, 1116, 1060 and $1025 \mathrm{~cm}^{-1}$ can be mainly observed in this IR spectrum (Figure $3 b$ ). All vibrations are related to pyranosyl rings among which the band at $1116 \mathrm{~cm}^{-1}$ corresponds to the $\mathrm{C}-\mathrm{OH}$ skeletal vibration, while $1060 \mathrm{~cm}^{-1}$ is associated with the $\mathrm{C}-\mathrm{O}-\mathrm{C}$ ether linkage of skeletal vibration and $1025 \mathrm{~cm}^{-1}$ is attributed to $\mathrm{C}-\mathrm{O}$ stretching vibration characteristic of cellulose. The band at about $1374 \mathrm{~cm}^{-1}$ was pronounced and the glycosidic bond vibration was detected at $901 \mathrm{~cm}^{-1}$. The band at $1322 \mathrm{~cm}^{-1}$ has a contribution of $\mathrm{C}-\mathrm{C}$ and $\mathrm{C}-\mathrm{O}$ skeletal vibrations. In this spectrum negligible, although visible absorption bands of lignin at 1228 and at $1267 \mathrm{~cm}^{-1}$, associated with $\mathrm{C}-\mathrm{O}$ stretching vibrations of the respective syringil and guaiacyl methoxyl groups are also noticed. The strongest band can be noticed at $1654 \mathrm{~cm}^{-1}$ and it is associated with $\mathrm{C}=\mathrm{O}$ stretching in conjugated para-substituted aryl ketones present in the lignin structure. Additionally, a band at $996 \mathrm{~cm}^{-1}$ indicates the existence of arabinose (arabinosyl side chains). Moreover, the band at $1738 \mathrm{~cm}^{-1}$ responsible for the hemicellulose-lignin interaction is absent in the cellulose-rich sample spectrum. However, the negligible band at $1718 \mathrm{~cm}^{-1}$ is attributed to $\mathrm{C}=\mathrm{O}$ stretching in unconjugated ketone, and carbonyl and ester groups also appear.

The evaluation of FTIR spectra of MBGS samples (Figure $3 b-c$ ) indicates that a successful modification was attained in both cases regarding different surfactant concentrations. The spectra of MBGS1 and MBGS2 samples demonstrated great similarities, especially for the characteristic region $1800-800 \mathrm{~cm}^{-1}$. The results of spectroscopy FTIR analysis revealed that the interaction of BGS with HTAC led to the presence of new chemical groups $\left(-\mathrm{CH}_{2}-,-\mathrm{CH}_{3}\right.$ and quaternary ammonium $-\mathrm{N}^{+} \mathrm{R}_{3}$ groups) on the MBGS surface. Thus, two sharp peaks in the FTIR spectra of both MBGS1 and MBGS2 samples at about 2945 and $2850 \mathrm{~cm}^{-1}$ are associated with asymmetric and symmetric stretching of $\mathrm{C}-\mathrm{H}$ bonds which are characteristic of $\mathrm{CH}_{2}$ and $\mathrm{CH}_{3}$ groups present in the aliphatic chain (tail) of HTAC molecule (Figure 3d). Most importantly, these FTIR spectra (Figure 3b-c) show the emergence of a new weak band at $1482 \mathrm{~cm}^{-1}$, corresponding to the $\mathrm{C}-\mathrm{H}$ bending vibration from the quaternary $-\mathrm{N}^{+}-$ $\left(\mathrm{CH}_{3}\right)_{3}$ functional group [42]. These observations clearly indicate the incorporation of a cationic $\mathrm{N}^{+} R_{4}$ group onto the sorbent surface. On the other hand, the differences between the IR spectra of MBGS1 (after HTAC sorption of $0.58 \mathrm{mmol} \mathrm{g}^{-1}$ ) and MBGS2 (after HTAC sorption of $1.28 \mathrm{mmol} \mathrm{g}^{-1}$ ) are in the intensities of $\mathrm{v}(\mathrm{CH})$ bands (at ca. $2945 \mathrm{~cm}^{-1}, 2925 \mathrm{~cm}^{-1}$ and $2850 \mathrm{~cm}^{-1}$ ) of the sorbed surfactant, and in the extent of perturbation of the hydroxyl IR bands. As the amount of the sorbed surfactant increases (from 0.58 to $1.28 \mathrm{mmol} \mathrm{g}^{-1}$ ), the frequency of the perturbed hydroxyl bands shifts downwards (from 3430 to about $3250 \mathrm{~cm}^{-1}$ ). The FTIR spectra thus point to the importance of hydroxyl groups in the sorption of the surfactant. Namely, it is well known that there is a difference in the sorption mechanism of cationic surfactants below and above the CMC $\left(1.28 \mathrm{mmol} \mathrm{dm}^{-3}\right)$. The difference was that below the CMC, the interaction between the cationic surfactant and the biomass surface with an opposite charge was due to electrostatic binding between both charges. Above the CMC, the interaction was both the electrostatic binding between the head groups and the biomass surface, as well as the hydrophobic inter- 
action between the tail groups of surfactants [6]. In the case of MBGS, the hydrophobic interaction between the tail groups appears to be a major driving force for surfactant sorption.

\section{Sorption isotherms of the cationic surfactant}

The sorption isotherms of the cationic HTAC surfactant on the BGS biomass are shown in Figure 4. When MBGS2 sample was analyzed, the sorption isotherm clearly displayed a five-region shape. In region I, the amount of the sorbed surfactant was low and did not exceed $20 \mu \mathrm{mol} \mathrm{g}{ }^{-1}$. When the free surfactant concentration reached a critical level, a significant increase in sorption (onset of region II) was noted. The sorption was slowed as the sorption attained a certain level (region III). Furthermore, the surfactant concentration was continuously increased (region IV) until it reached a constant level (region $\mathrm{V}$ ). It seems that the sorption remains low at the beginning, and increases slowly in region I despite the presence of a relatively high amount of available negative sites on the BGS surface. In this region, surfactant monomers are sorbed via the electrostatic interaction between surfactant head groups and negative sites on the BGS surface. Hydrocarbon tails are supposed to lie flat on the substrate to minimize their contact area with water molecules. The relatively high surface occupied by the sorbed species reduces the possibility of sorption of other surfactant molecules. The steep increase in the slope of sorption isotherm in region II is the result of the change in the conformation of sorbed molecules from a flat to a perpendicular orientation, where alkyl chains form highly packed aggregates, minimizing their contact area with water molecules, and therefore increasing the entropy of the system. In this region, the electrostatic interaction between the charged head groups and negative sites on the BGS surface is still present since the sorbed amount is not sufficient to neutralize the surface charge. Surfactant molecules are still sorbed with head groups facing toward the surface, and self-association leads to the formation of monolayer aggregates. Region III appears when the sorbed amount reaches over $50 \%$ of the BGS total negative sites. The decrease in the slope of the isotherm could be attributed to the progressive neutralization of the BGS surface, and to the subsequent reduction of the electrostatic surface/head group attraction, as well as the increase of the repulsion between surfactant head groups. The restart of sorption in region IV occurs when the substrate charge is close to neutral (the amount of sorbed equivalents is close to the corresponding density of the negative sites). The sorption in this domain may occur with a bilayer conformation, with surfactant head groups facing into the solution. The solution activity of the surfactant is now sufficient to overcome the electrostatic repulsion among head groups and to continue the growth of the aggregated domains. The stabilization of the sorption in region $\mathrm{V}$ may be attributed to the saturation of the bilayer. This region occurs at the surfactant concentration lower than or close to the CMC.

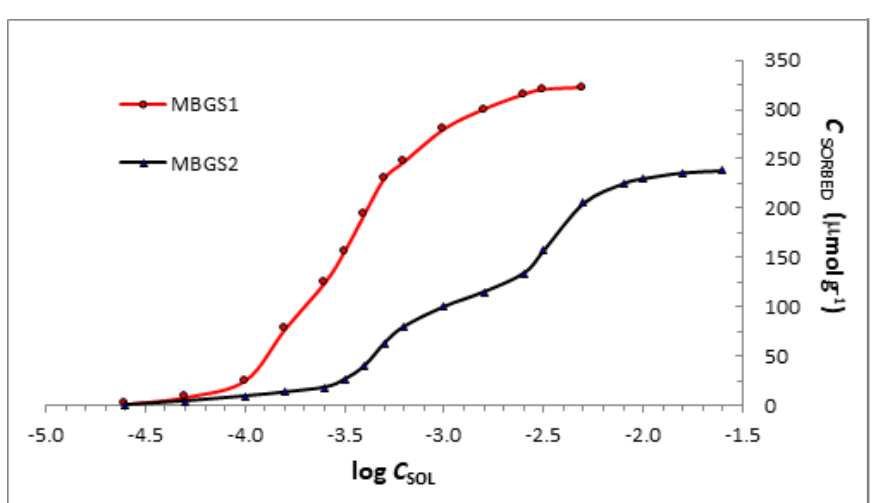

Figure 4. Sorption isotherm of HTAC cationic surfactants onto the BGS biomass according to a linear-log scale, at $\mathrm{pH} 6.8$ and in the absence of any added salts

On the other hand, the MBGS1 sample showed a three-region sorption isotherm, which was interpreted as reflecting the generation of the mainly monolayer structure. The three-region isotherm indicates that strong hydrophobic interactions among HTAC alkyl chains enabled the electrostatic repulsion forces to be overcome, thus inducing a continuous transition from region I to region IV. This trend is in agreement with the hypothesis of surfactant self-association into monolayer and bilayer structures. This hypothesis on the mechanisms of surfactant self-assembly at the surface of the BGS biomass was based on the different phenomena reported to take place in the interaction of ionic surfactants with lignoceIlulosic surfaces $[6,9]$. Since the validity of this sorption process for surfactant/biomass systems has not been proven yet, in this study further arguments to support the defining of a possible model are provided.

\section{Biomass-surfactant interaction mechanism}

Namely, it is known that cellulose and lignin are the basic constituents of BGS biomass. Cellulose polymer skeleton of the biomass consists mainly of long hydrophilic chains composed of glucopyranose units. However, the cellulose naturally possesses a small number of hydrophobic side chains, i.e. terminal groups with multiple $\mathrm{C}$-atoms, which is particularly characteristic in the case of the modified biomass. This hydrophobicity is particularly pronounced in aromatic and aliphatic hydrocarbon chains of lignin. Exactly these hydrophobic groups represent areas of high affinity for the interaction (hydrophobic association) of the biomass with surfactant, whereby a complex type of the product arises $[14,43]$. According to the literature [6], the complexing phenomenon on the biomass surface depends on several factors such as: surface properties of the solid phase, the surfactants structure, the counterion type, the ionic strength in the solution, the $\mathrm{pH}$ value of the medium and the temperature. Depending on these factors, and above all concentration, surfactant molecules may be self-organizing on the biomass surface through multiple forms: as monolayer (called hemimicelle), bilayer (called admicelle), spherical and cylindrical aggregates (Figure 5). These 
organized structures can be continuously distributed along the surface, or they can form patches of aggregated domains $[6,9]$. Sorption isotherms usually provide the information concerning the onset of surfactant selfassembly occurring when the solution concentration and the surface excess are altered.

According to theoretical models [6], in the region I (Figure 5) typical for a low-concentration domain, cationic surfactants are mostly sorbed individually on localized centers with the opposite charge through an ion exchange mechanism. Sorption is sparse with no interaction among sorbed surfactant molecules. Up to a critical surfactant concentration, which corresponds to the boundary between regions I and II, sorbed monomers begin to associate through lateral interactions, inducing the formation of monolayered (hemimicelle) and bilayered (admicelle) aggregates. This concentration (called the hemimicelle concentration) occurs well below the surfactant CMC. The generation of surfactant aggregates boosts monomer sorption and explains the abrupt rise in the S-shaped isotherm. A further increase in the surfactant concentration leads to the progressive stabilization of the surfactant sorption up to the satura- tion of the interface near the CMC. The driving force behind surfactant aggregation is the transfer of surfactant alkyl chains from an aqueous to a hydrocarbon medium (hemimicelle and admicelle core) during self-association. This attractive interaction is counteracted by electrostatic repulsion forces between charged head-groups within surfactant aggregates. Thus, when dispersive and electrostatic-repulsive forces are balanced, a saturation plateau is attained (region III, Figure 5). The last region is characterized by the concentration of surfactants above the CMC, where spherical micelles in the solution dominate in addition to the formed double layer. Early tests of this complex phenomenon have shown that surfactants with $\mathrm{C} 12$ hydrocarbon chains mainly form monolayered (hemimicelle) aggregates, while the characteristic of C15/C16 surfactants is that they generate bilayered (admicelle) aggregates on the cellulose surface due to the greater contribution of hydrophobic interaction, as well as negligible electrostatic repulsion between the polar heads. In addition, longer hydrocarbon chains also have a significant effect on reducing the initial surfactant concentration (below the $\mathrm{CMC}$ ) in order to avoid the formation of spherical micelles in the solution.
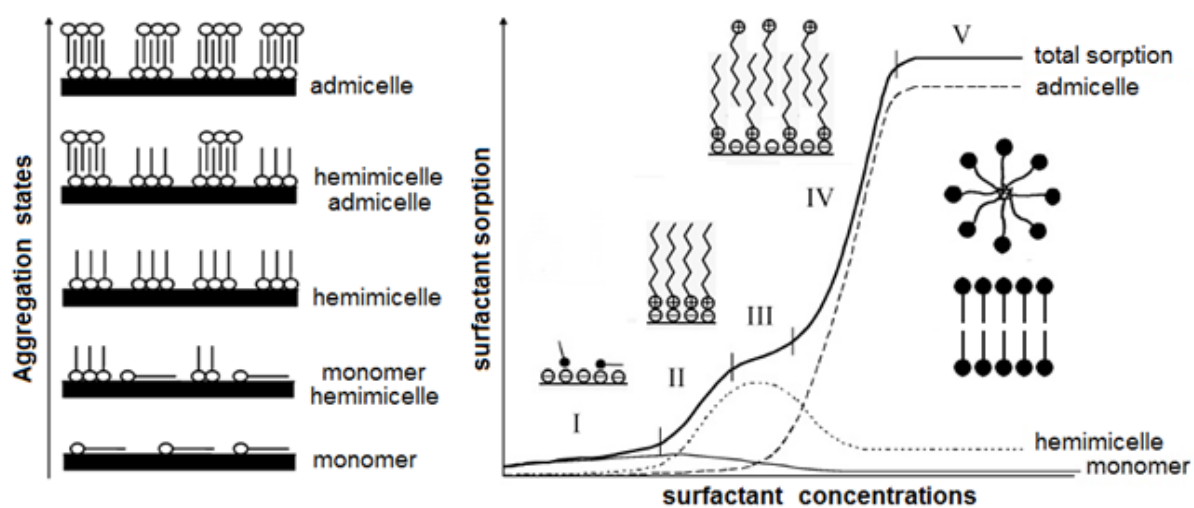

Figure 5. Possible aggregation states and sorption isotherms of cationic surfactants at the surface of negatively charged biomass [6]

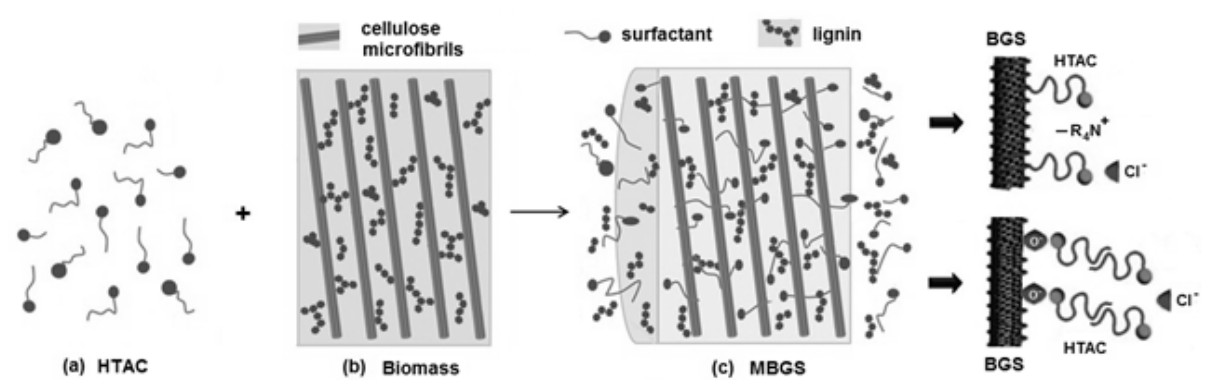

Figure 6. Schematic illustration of proposed mechanisms for the biomass modification and the formation of surfactant complex aggregates on the BGS biomass surface

Depending on the HTAC concentration, two possible mechanisms have been proposed for the formation of surfactant aggregates on the BGS biomass surface (Figure 6). According to one interpretation [44], the nonpolar alkyl part of the surfactant (a long hydrocarbon chain) probably interacts with the surface of the lignocellulos- ic biomass through hydrophobic binding (characteristic of the surfactant), wherein the surfactant polar part (the positive chemical group) is directed to the solution. Bound in this way, the surfactants make the surface of the biomass positive and represent active centers for the subsequent sorption of negatively charged anionic species 
from the solution. According to another interpretation [45], the interaction of cationic surfactants with the BGS surface can be controlled by the surface charge in two ways. Namely, on the surface of the lignocellulosic biomass $-\mathrm{OH}$ groups with partially negative charge dominate. Some of these functional groups (in the alkaline medium) lose hydrogen ions, forming the -ONa groups (alkali-cellulose). Accordingly, the possible mechanism is the electrostatic attraction between the positive head of the cationic surfactant and the partially negative $-\mathrm{OH}$ group of the glucopyranose unit, or the cationic change of surfactants with surface - $\mathrm{O}^{-} \mathrm{Na}^{+}$groups, when the monolayered (hemimicelle) aggregates formation on the MBGS1 surface occurs. In the case of MBGS2 sorbent, when the surfactant concentration is above the CMC, there is an increased surfactant sorption at the boundary surface with the formation of bilayered (admicelle) complex aggregates, due to the hydrophobically-hydrophobic attractive interactions of the surfactant hydrocarbon chains (tail) from the solution with the already sorbed surfactant monomers on the biomass surface [46]. Nevertheless, regardless of the presumed mechanism, the biomass surface in both cases is characterized by a positive potential, which corresponds to the process of removing negatively charged anionic pollutants from the solution. Regarding the reaction conditions, it was found that the reaction time and temperature did not have a significant effect on the amount of introduced cationic groups in the biomass structure [5].

On the other hand, it should be borne in mind that surfactant counterion play a very important role in the self-assembly of surfactant molecules on the biomass surface during modification. The type of counterion and its effect have an important theoretical contribution to understanding the mechanism and improving the sorption efficiency of target anionic species from the solution [15]. Namely, the sorption of inorganic anions on the MBGS sorbent is carried out according to the principle of the ion exchange with surfactant counterions, due to their low affinity to the active centers [44]. The positively charged head groups are balanced by counterions, and the sorption or the exchange of other anionic constituents involves the replacement of weakly held counterions by more strongly held counterions. It is therefore important, especially from a practical aspect, to select the initial surfactant counterion in order to achieve the maximum sorption of the target anion species when removed from the contaminated solution. In this respect, it is possible to use the well-known fact that the effect of counterions on stabilizing the surfactant micelle formation in the solution follow the lyotropic series of anions (citrates $>$ tartrates $>$ sulphates $>$ acetates $>$ chlorides $>$ bromides $>$ nitrates $>$ chlorates $>$ iodides $>$ thiocyanates) or cations $\left(\mathrm{Mg}^{2+}\right.$, $\mathrm{Ca}^{2+}, \mathrm{Sr}^{2+}, \mathrm{Ba}^{2+}, \mathrm{Li}^{+}, \mathrm{Na}^{+}, \mathrm{K}^{+}, \mathrm{Rb}^{+}, \mathrm{Cs}^{+}$) [47]. In addition, the research of the surfactants self-assembly in the function of counterions has shown that greater monolayer of HTAC occurred when $\mathrm{Cl}^{-}$, rather than $\mathrm{Br}^{-}$or $\mathrm{I}^{-}$, was the counterion [16]. This observation is consistent with the stronger interaction between surfactant and $\mathrm{Br}^{-}$(or $\mathrm{I}^{-}$) compared to that with $\mathrm{Cl}^{-}$ion. Thus, the bilayer formation can be minimized when $\mathrm{Cl}^{-}$is the counterion (Figure 7). In this way, differences in surfactant counterions can result in different amounts of surfactant sorbed to yield a stable bilayered or patchy bilayered aggregate on the sorbent surface [6].
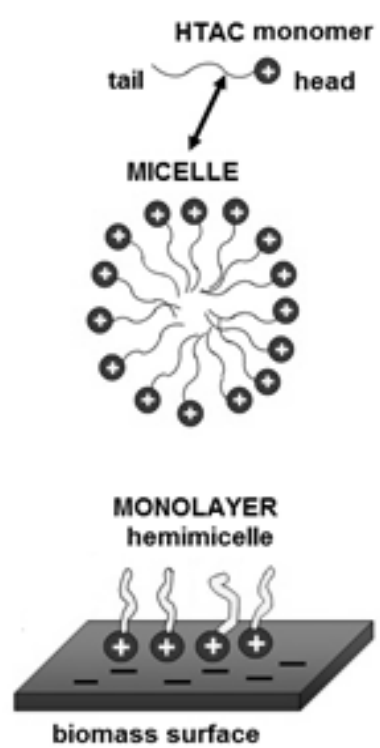

Figure 7. Sorption of surfactant molecules as a monolayer, patchy bilayer, and bilayer on solid surfaces; monovalent $\mathrm{Cl}^{-}$anions (counterions) are shown balancing the charge on outward-pointing surfactant head groups [44] 
Test efficiency of MBGS sorbents

The efficiency of cationic sorbents was estimated using the sorption capacity to remove phosphate and nitrate anions from the aqueous solution. In this sense, a series of experiments for phosphate removal from the solution of the initial concentration of $10 \mathrm{mg} \mathrm{P} \mathrm{dm}^{-3}$ and the removal of nitrate from the solution of the initial concentration of $10 \mathrm{mg} \mathrm{N} \mathrm{dm}^{-3}$, with a sorbent dose of $2 \mathrm{~g} \mathrm{dm}^{-3}$ was carried out in the batch system. These initial concentrations were selected in accordance with the quality standards for the wastewater treatment in eutrophication sensitive regions (Council Directive 91/271/EEC). The reaction conditions of the sorption process (mixing rate of $150 \mathrm{rpm}$, contact time $60 \mathrm{~min}$, temperature $25^{\circ} \mathrm{C}, \mathrm{pH}$ 6.8) were selected in accordance with the literature data, which proved to be optimal for these purposes $[48,49]$. Comparative results of the sorbents efficiency, relative to the initial biomass, are shown in Table 3.

Table 3. Efficiency of phosphate and nitrate sorption using cationic sorbents ( $Q_{e}$ - equilibrium sorption capacity)

\begin{tabular}{ccccc}
\hline \multirow{2}{*}{ Material } & \multicolumn{2}{c}{ Phosphate $\left(10 \mathrm{mg} \mathrm{P} \mathrm{dm}^{-3}\right)$} & \multicolumn{2}{c}{ Nitrate $\left(10 \mathrm{mg} \mathrm{N} \mathrm{dm}^{-3}\right)$} \\
\cline { 2 - 5 } & $Q_{e}\left(\mathrm{mg} \mathrm{g}^{-1}\right)$ & $\%$ & $Q_{e}\left(\mathrm{mg} \mathrm{g}^{-1}\right)$ & $\%$ \\
\hline \multirow{2}{*}{ BGS biomass } & $0.04 \pm 0.02$ & 0.8 & $0.03 \pm 0.01$ & 0.6 \\
MBGS1 & $2.03 \pm 0.08$ & 40.6 & $1.11 \pm 0.12$ & 22.2 \\
MBGS2 & $1.95 \pm 0.07$ & 39.2 & $1.08 \pm 0.06$ & 21.6 \\
\hline
\end{tabular}

The efficiency test of MBGS1 and MBGS2 sorbents for removing phosphate and nitrate anions from aqueous solutions (the same initial concentration, under the same reaction conditions) confirmed the success of the starting biomass modification. It was found that the BGS biomass does not show sorption properties for the investigated anions $(<1 \%)$. However, both sorbents showed an almost identical degree of the removal of the examined anions (about $40 \%$ for phosphates and $22 \%$ for nitrates). As expected, in both cases the sorption capacities $\left(Q_{e}\right)$ were independent of the applied surfactant concentration for the biomass modification (below and above the $\mathrm{CMC}$ ). This can be understandable if the model of the biomass modification by surfactant is taken into account for interpretation (Figure 6). It is clear that the formation of surfactant complex aggregates on the biomass surface increases the number of added cationic groups, but not the number of available active centers for the interac- tion with the present anions in the solution [9].

Sorption of anions from the solution on the MBGS biosorbent surface can be observed in two ways, depending on the mechanism of monolayer or bilayer complex aggregates formation [9]. The first way of surfactants interaction (monolayer) is more likely at lower initial surfactant concentrations, when the ion exchange capacity is reached at almost $100 \%$ or slightly lower. The second type of interaction (bilayer) is characteristic for higher concentrations of surfactants, usually above the CMC [9]. Given that the experiment provides a quantity of HTAC surfactants greater than the exchange capacity of biomass, it can be assumed that bilayer (or patchy bilayer) aggregates on the biomass surface are formed. However, the principle of removing anion from the solution was identical in both cases. In order to achieve anions sorption, the modified biomass surface must be enriched with positively charged groups (exchange active centers). These active centers are in fact positively charged $-\mathrm{NR}_{4}{ }^{+}$groups (HTAC surfactant heads) that are stabilized by counterions ( $\mathrm{Cl}^{-}$ions). In this case, the positively charged heads are directed towards the solution, which makes the surface of the modified biomass suitable for the anion sorption process (Figure 8a). The sorption of other negative anionic species (phosphate and nitrate in this case) on MBGS sorbent can be attributed to the formation of a surfactant-anion complex [44]. Thus, the anion sorption mechanism implies the ion exchange. In this way, the mechanism involves the replacement of weakly held counterions $\left(\mathrm{Cl}^{-}\right)$by more strongly held counterions $\left(\mathrm{H}_{2} \mathrm{PO}_{4}^{-}\right.$or $\left.\mathrm{NO}_{3}{ }^{-}\right)$on the biomass surface active centers $\left(-\mathrm{NR}_{4}^{+}\right)$. In addition, the surfactant amount present in the solution, together with the surfactant chemical nature (the hydrocarbon chain length and the counterion type), has a very strong effect on the rheological properties of the aqueous solution (i.e. viscosity). This will actually affect the anion diffusion through the solution during the sorption process, and thus the degree of the anion removal [50]. The corresponding model of MBGS sorbent after the anions removal from the solution is presented in Figure 8b. This model is confirmed by the results of the morphological SEM analysis. Similar models of lignocellulosic biomass modification with other cationic surfactants, as well as the mechanisms for removing some anions (phosphate, nitrate, sulphate, chromate) or anionic dyes from contaminated aqueous solutions, were pointed out by other authors $[9,10,48]$.

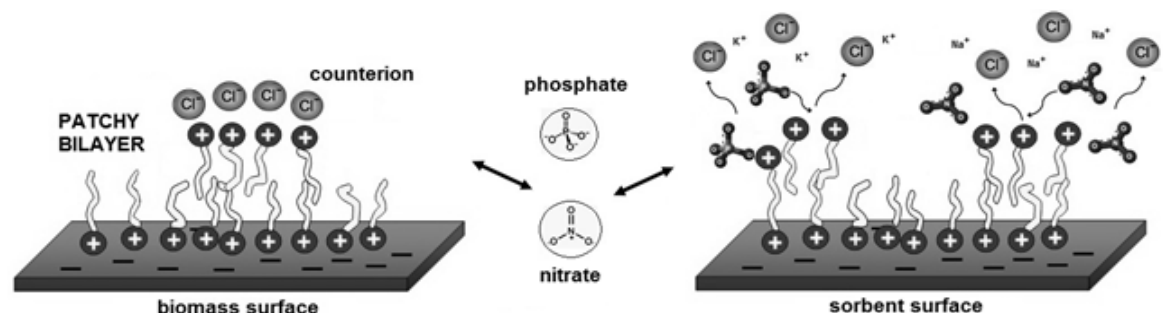

Figure 8. Schematic illustration of the HTAC self-organization on the BGS biomass surface and the sorption model of anionic species (phosphate or nitrate) from the aqueous solution 
SEM analysis of the surfactant/biomass system

The morphology of the BGS biomass and surface properties of the MBGS sorbent before and after the sorption of anionic pollutants were analyzed by scanning electron microscope (SEM) methods. The SEM images of the BGS biomass, a surfactant modified BGS sample before anions sorption, and MBGS sorbent after the sorption of anionic pollutants are shown in Figure 9. There are obvious morphological differences of the SEM images of BGS and MBGS, as shown in Figure 9. At macro-level, BGS is mainly composed of tiny disorganized plant vessels of various dimensions (30-50 $\mu \mathrm{m})$, sharp edges and diverse morphology (Figure 9a), mainly containing cellulose, hemicelluloses and lignin. The SEM image indicates the channels existence of vertical and horizontal orientation, and a variety of cavities on the external surface. This image at $2 \mathrm{kx}$ magnification showed the irregular surface morphology and a porous structure of BGS, with micro-pores of different shapes and sizes (about 1-2 $\mu \mathrm{m}$ ). The surface morphology of MBGS was different from that of BGS. The SEM image of MBGS (Figure 9b) represents a compact, uneven and folded surface. The sharp edges of each microstructure now look less obvious. These facts can be attributed to overlapping the biomass surface with surfactant molecules during BGS modification. Likewise, this result indicated that a part of surfactant molecules is most probably arranged through a mode of bimolecular association (in MBGS2), or a popular monolayer coverage mode (in the case of BGS1). In addition, this SEM image shows a flexible and macro-porous surface, which should be benefit for the anionic pollutants removal from the aqueous solution. Also, the anions binding to the surfactant modified sorbent caused some further changes in the surface morphology of MBGS, as shown in Figure 9c. The sorption of phosphate and nitrate leads to coverage of HTAC molecules on MBGS surface and as the result, thicker channel walls, smaller macro-pores and fewer cavities on the external biomass surface can be observed compared to those prior to the sorption. This finding suggests that anionic pollutants sorption is closely related to the presence of represented chemical groups (quaternary ammonium) on the solid BGS surface, which is additionally confirmed by FTIR and elemental analysis, as already described.

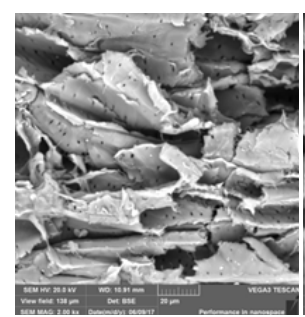

(a)

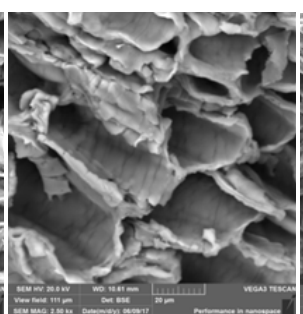

(b)

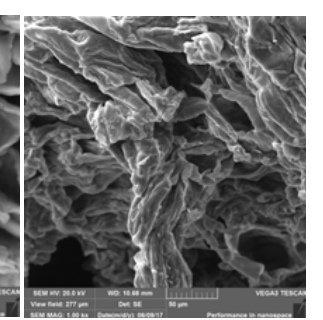

(c)
Figure 9. SEM images of BGS (a), surfactant modified BGS (b), and MBGS sorbent after the sorption of anionic (phosphate and nitrate) species (c)

\section{Conclusion}

The surface modification of the solid agricultural residue is very important to explore new applications. In this study, a cationic surfactant, hexadecyltrimethylammonium chloride $\left(\mathrm{HTAC}, \mathrm{CH}_{3}\left(\mathrm{CH}_{2}\right)_{15} \mathrm{~N}(\mathrm{Cl})\left(\mathrm{CH}_{3}\right)_{3}\right)$, was used to modify the bottle gourd shell (BGS) surface for the anions sorption enhancement. Functionalization of the BGS surface by the cationic HTAC surfactant was performed due to the introduction of stable positively charged groups on the surface, and to adjusting the surface energy characteristic to improve the biomass compatibility as a cationic sorbent. The modification was conducted under various HTAC concentrations (below and above $\mathrm{CMC}$ ) in order to impose a different degree of surface hydrophobicity. Several characterization methods, including FTIR, SEM, compositional and elemental analyses confirmed the surfactant modification of the BGS biomass. The results showed that new quaternary ammonium $\left(-\mathrm{N}^{+} \mathrm{R}_{3}\right)$ chemical groups appeared on the MBGS surface, which actually represent sorbent active centers for removing anionic pollutants from the aqueous solution. Based on the amount of added cationic groups in MBGS, the theoretical ion exchange capacity of $1.01 \mathrm{mEq} \mathrm{g}^{-1}$ was calculated. The isotherms of surfactant sorption provided the information regarding the self-assembly of the cationic HTAC surfactant onto the BGS surface. Depending on the HTAC concentration, two possible mechanisms have been proposed for the formation of surfactant aggregates. The efficiency of MBGS sorbent was estimated using the sorption capacity to remove phosphate (about $40 \%$ ) and nitrate (about $22 \%$ ) anions from the contaminated aqueous solution. Morphological SEM analysis of the post-sorption sample proved that the porous MBGS surface was covered with the cationic HTAC surfactant, which served as the main sorption sites for the investigated anions. Due to abundant availability and easy modification at relatively low cost, the application of the surfactant modified bottle gourd shell showed a promising alternative method for the wastewater treatment.

\section{Acknowledgements}

This work was financed by the Serbian Ministry of Education, Science, and Technological Development, Grants No. TR34012 and TR34008.

\section{References}

[1] X. Huang, H. Liu, S. Shang, X. Rao, J. Song, Preparation and characterization of polymeric surfactants based on epoxidized soybean oil grafted hydroxyethyl cellulose, Journal of Agricultural and Food Chemistry, 63 (2015) 9062 $-9068$.

[2] B. L. Peng, N. Dhar, H. L. Liu, K. C. Tam, Chemistry and applications of cellulose nanocrystal and its derivatives: a nanotechnology perspective, Canadian Journal of Chemical Engineering, 89 (2011) 1191 - 1206. 
[3] S. J. Eichhorn, Cellulose nanowhiskers: promising materials for advanced, applications, Soft Matter, 7 (2010) $303-315$.

[4] T. P. Delforno, A. G. L. Moura, D. Y. Okada, M. B. A. Varesche, Effect of biomass adaptation to the degradation of anionic surfactants in laundry wastewater using EGSB reactors, Bioresource Technology, 154 (2014) 114 - 121.

[5] A. Kaboorani, B. Riedl, Surface modification of cellulose nanocrystals (CNC) by a cationic surfactant, Industrial Crops and Products 65 (2015) $45-55$.

[6] S. Alila, S. Boufi, M. N. Belgacem, D. Beneventi, Adsorption of a cationic surfactant onto cellulosic fibers: I. Surface charge effects, Langmuir, 21 (2005) 8106 - 8113.

[7] K. Syverud, K. Xhanari, G. Chinga-Carrasco, Y. Yu, P. Stenius, Films made of cellulose nanofibrils: surface modification by adsorption of a cationic surfactant and characterization by computer-assisted electron microscopy, Journal of Nanoparticle Research, 13 (2011) 773 - 782.

[8] Y. Su, H. Cui, Q. Li, S. Gao, J. K. Shang, Strong adsorption of phosphate by amorphous zirconium oxide nanoparticles, Water Research, 47 (2013) 5018 - 5026.

[9] M. Foroughi-dahr, H. Abolghasemi, M. Esmaieli, G. Nazari, B. Rasem, Experimental study on the adsorptive behavior of Congo red in cationic surfactant-modified tea waste, Process Safety and Environmental Protection, 95 (2015) $226-236$.

[10] H. Chen, J. Zhao, G. Dai, Silkworm exuviae - a new non-conventional and low-cost adsorbent for removal of methylene blue from aqueous solutions, Journal of Hazardous Materials, 186 (2011) 1320 - 1327.

[11] A. Bingol, H. Ucun, Y. K. Bayhan, A. Karagunduz, A. Cakici, B. Keskinler, Removal of chromate anions from aqueous stream by a cationic surfactant-modified yeast, Bioresource Technology, 94 (2004) 245 - 249.

[12] S. Ibrahim, H-M. Ang, S. Wang, Removal of emulsified food and mineral oils from wastewater using surfactant modified barley straw, Bioresource Technology, 100 (2009) 5744 5749 .

[13] C. Namasivayam, M. V. Sureshkumar, Modelling thiocyanate adsorption onto surfactant-modified coir pith, an agricultural solid waste, Process Safety and Environment Protection, 85 (2007) 521 - 525.

[14] M. V. Sureshkumar, C. Namasivayam, Adsorption behavior of direct Red 12B and Rhodamine B from water onto surfactant-modified coconut coir pith, Colloids and Surfaces A: Physicochemical and Engineering Aspects, 317 (2008) $277-283$.

[15] A. K. Bansiwal, S. S. Rayalu, N. K. Labhasetwar, A. A. Juwarkar, S. Devotta, Surfactant-modified zeolite as a slow release fertilizer for phosphorus, Journal of Agricultural and Food Chemistry, 54 (2006) 4773 - 4779.

[16] G. Morel, N. Ouazzani, A. Graciaa, J. Lachaise, Surfactant modified ultrafiltration for nitrate ion removal, Journal of Membrane Science 134 (1997) 47 - 57.

[17] NRCS, Lagenaria siceraria, Natural Resources Conservation Service Plants Database, USDA (https:// plants.usda.gov), retrieved 10 August 2017.

[18] R. P. Prajapati, M. Kalariya, S. K. Parmar, N. R. Sheth, Phytochemical and pharmacological review of Lagenaria sicereria, Journal of Ayurveda and Integrative Medicine, 1(4) (2010) 266 - 272.

[19] A. S. Rahman, Bottle gourd (Lagenaria siceraria): A vegetable for good health, Natural Product Radiance, 2 (2003) 249 - 250.
[20] D. L. Mitic-Stojanovic, A. Zarubica, M. Purenovic, D. Bojic, T. Andjelkovic, A. Lj. Bojic, Biosorptive removal of $\mathrm{Pb}^{2+}, \mathrm{Cd}^{2+}$ and $\mathrm{Zn}^{2+}$ ions from water by Lagenaria vulgaris shell, Water SA, 37(3) (2011) $303-312$.

[21] G. S. Nikolić, D. Z. Marković-Nikolić, M. D. Cakić, A Lj. Bojić, D. Cvetković, D. V. Bojić, Synthesis and characterization of quaternary anion exchanger based on natural lignocellulosic material, 12th symposium "Novel technologies and economic development", Faculty of Technology in Leskovac, 20-21 October 2017, Leskovac, Serbia [CD ROM].

[22] D. Z. Marković-Nikolić, M. D. Cakić, A. Lj. Bojić, G. S. Nikolić, Kinetic and thermodynamic studies on orthophosphate biosorption using the quaternary ammonium modified Lagenaria vulgaris shell, XII International Symposium "Recycling technologies and sustainable development", Technical Faculty in Bor, University of Belgrade, 13-15 September 2017, Bor Lake, Serbia.

[23] D. V. Bojić, G. S. Nikolić, J. Z. Mitrović, M. D. Radović, M. M. Petrović, D. Z. Marković, A. Lj. Bojić, Kinetic, equilibrium and thermodynamic studies of $\mathrm{Ni}$ (II) ions sorption on sulfuric acid treated Lagenaria vulgaris shell, Chemical Industry \& Chemical Engineering Quarterly, 22(3) (2016) 235 - 247.

[24] M. Stanković, N. Krstić, I. Slipper, J. Mitrović, M. Radović, D. Bojić, A. Bojić, Chemically modified Lagenaria vulgaris as an biosorbent for the removal of $\mathrm{Cu}(\mathrm{II})$ from water, Australian Journal of Chemistry, 66(2) (2013) 227 - 236.

[25] D. V. Bojić, M. S. Ranđelović, A. R. Zarubica, J. Z. Mitrović, M. D. Radović, M. M. Purenović, A. Lj. Bojić, Comparison of new biosorbents based on chemically modified Lagenaria vulgaris shell, Desalination and Water Treatment, 51(3436) (2013) 6871 - 6881.

[26] A. Kaboorani, B. Riedl, P. Blanchet, M. Fellin, O. Hosseinaei, S. Wang, Cellulose nanocrystal (CNC): a renewable nanomaterial for wood adhesives, European Polymer Journal, 48 (2012) 1829 - 1837.

[27] Z. H. Li, R. S. Bowman, Sorption of perchloroethylene by surfactant-modified zeolite as controlled by surfactant loading, Environmental Science \& Technology, 32 (1998) $2278-2282$.

[28] J. Wagner, H. Chen, B. J. Brownawell, J. C. Westall, Use of cationic surfactants to modify soil surfaces to promote sorption and retard migration of hydrophobic organic compounds, Environmental Science \& Technology, 28 (1994) 231 - 237.

[29] M. Salajkova, L. A. Berglund, Q. Zhou, Hydrophobic cellulose nanocrystals modified with quaternary ammonium salts, Journal of Materials Chemistry, 22 (2012) 19798 . 19805.

[30] G. R. Alther, Removing oils from water with organoclays, Journal AWWA (American Water Works Association), 94(7) (2002) $115-121$.

[31] D. Z. Marković-Nikolić, Lj. Balanović, A. Lj. Bojić, M. D. Cakić, D. Cvetković, G. S. Nikolić, Structural and biosorption characteristics of the cationic surfactant-modified Lagenaria vulgaris shell, XII International Symposium "Recycling technologies and sustainable development", Technical Faculty in Bor, University of Belgrade, 13-15 September 2017, Bor Lake, Serbia.

[32] S. Kamel, Nanotechnology and its applications in lignocellulosic composites, a mini review, eXPRESS Polymer Letters, 1 (2007) 546 - 575.

[33] B. Gao, L. Yang, X. Wang, J. Zhao, G. Sheng, Influence of modified soils on the removal of diesel fuel oil from 
water and the growth of oil degradation micro-organism, Chemosphere, 41 (2001) 419 - 426.

[34] APHA, Standard methods for the examination of water and wastewater, 20th edition, M. A. H. Franson ed., American Public Health Association, Washington, 2000.

[35] A. Singh, R. K. Sharma, M. Agrawal, F. M. Marshall, Risk assessment of heavy metal toxicity through contaminated vegetables from waste water irrigated area of Varanasi, Tropical Ecology (India), 51(2S) (2010) 375 - 387.

[36] L. H. Wartelle, W. E. Marshall, Quaternized agricultural by-products as anion exchange resins, Journal of Environmental Management, 78(2) (2006) 157 - 162.

[37] S. Hena, S. Atikah, H. Ahmad, Removal of phosphate ion from water using chemically modified biomass of sugarcane bagasse, International Journal of Engineering Science, 4(1) (2015) 51 - 62.

[38] G. Tan, D. Xiao, Adsorption of cadmium ion from aqueous solution by ground wheat stems, Journal of Hazardous Materials, 164(2-3) (2009) 1359 - 1363.

[39] K. Riahi, B. B. Thayer, A. B. Mammou, A. B. Ammar, M. H. Jaafoura, Biosorption characteristics of phosphates from aqueous solution onto Phoenix dactylifera L. date palm fibers, Journal of Hazardous Materials, 170 (2009) 511 . 519.

[40] Z. Ismail, Kinetic study for phosphate removal from water by recycled date-palm wastes as agricultural by-products, International Journal of Environmental Studies, 69(1) (2012) 135 - 149.

[41] A. M. da Costa Lopes, K. G. Joao, D. F. Rubik, E. BogelLukasik, L. C. Duarte, J. Andreaus, R. Bogel-Lukasik, Pretreatment of lignocellulosic biomass using ionic liquids: Wheat straw fractionation, Bioresource Technology, 142
(2013) 198 - 208.

[42] R. M. Silverstein, G. C. Bressler, T. C. Morril, Spectrometric Identification of Organic Compounds, 5th ed., John Wiley \& Sons, New Jersey, 2005.

[43] U. Kastner, H. Hoffmann, R. Donges, R. Ehrler, Interactions between modified hydroxyethyl cellulose (HEC) and surfactants, Colloids and Surfaces A, 112 (1996) 209 - 225

[44] Z. Li, R. S. Bowman, Counterion effects on the sorption of cationic surfactant and chromate on natural clinoptilolite, Environmental Science \& Technology, 31 (1997) 2407 2412.

[45] B. N. Chen, C. W. Hui, G. McKay, Pore-surface diffusion modeling for dyes from effluent on pith, Langmuir, 17(3) (2001) 740 - 748.

[46] Z. Li, C. A. Willms, K. Kniola, Removal of anionic contaminants using surfactant modified palygorskite and sepiolite, Clays and Clay Minerals, 51 (2003) 445 - 451.

[47] M. Antonietti, Colloid Chemistry II, Springer, Germany, 2003.

[48] T. A. H. Nguyen, H. H. Ngo, W. Guo, T. V. Nguyen, Phosphorous removal from aqueous solutions by agricultural by-products: A critical review, Journal of Water Sustainability, 2(3) (2012) 193 - 207.

[49] P. Loganathan, S. Vigneswaran, J. Kandasamy, Enhanced removal of nitrate from water using surface modification of adsorbents - A review, Journal of Environmental Management, 131 (2013) 363 - 374.

[50] R. Tanaka, J. Meadows, P. A. Williams, G. O. Phillips, Interaction of hydrophobically modified (hydroxyethyl) cellulose with various added surfactants, Macromolecules, 25 (1992) $1304-1310$.

Izvod

\section{PRIPREMA I KORIŠĆENJE KATJONSKOG SORBENTA NA BAZI TENZIDOM MODIFIKOVANE KORE TIKVE SUDOVNJAČE}

Dragana Z. Marković-Nikolić ${ }^{1},{ }^{2}$, Aleksandar Lj. Bojić ${ }^{2}$, Goran Petković1, Nebojša Ristić ${ }^{1}$, Milorad D. Cakić ${ }^{3}$, Goran S. Nikolić ${ }^{3}$

(ORIGINALNI NAUČNI RAD) UDK 582.681.71:661.185:66.081

\footnotetext{
${ }^{1}$ Visoka tehnološko umetnička strukovna škola, Leskovac, Srbija

2Departman za hemiju, Prirodno-matematički fakultet, Univerzitet u Nišu, Niš, Srbija

${ }^{3}$ Tehnološki fakultet, Univerzitet u Nišu, Leskovac, Srbija
}

Kora tikve sudovnjače (BGS), kao čvrst poljoprivredni ostatak Lagenaria vulgaris Ser., hemijski je modifikovana pomoću katjonskog tenzida, heksadeciltrimetilamonijum hlorida (HTAC). Uspešnost ove modifikacije je potvrđena pomoću FTIR spektroskopije. Hemijska karakterizacija lignocelulozne BGS biomase i tenzidom modifikovane kore tikve sudovnjače (MBGS) izvršena je metodama kompozitne i elementne analize. Količina sorbovanog tenzida na površini BGS-a određivana je u funkciji koncentracije preostalog tenzida u rastvoru. Za verifikovanje modela samo-organizovanja katjonskog tenzida tokom sorpcije na suprotno naelektrisanom MBGS supstratu korišćene su sorpcione izoterme. Ponašanje tenzid/BGS sistema je opisano na osnovu oblika ovih sorpcionih izotermi. Tenzidom modifikovana kora je testirana kao sorbent za uklanjanje fosfata i nitrata iz kontaminiranih vodenih rastvora. Sorpcija anionskih zagađivača na MBGS-u izvođena je serijom sorpcionih eksperimenata u šaržnom režimu na $20^{\circ} \mathrm{C}$. Utvrđeno je da MBGS sorbuje $40 \%$ fosfata i $22 \%$ nitrata iz rastvora. Za uklanjanje anjona iz ra-stvora odgovoran je mehanizam sorpcije koji uključuje jonsku izmenu. Morfologija i površinska svojstva MBGS sorbenta, pre i nakon sorpcije anjonskih zagađivača, analizirani su SEM metodom. Prednost MBGS sorbenta, u poređenju sa drugim netenzidnim sorbentima, je u tome što se može koristiti za uklanjanje anjonskih zagađivača ne samo iz vodenih rastvora, već i iz uljanih otpadnih emulzija ili drugih nepolarnih efluenata.
Ključne reči: tikva sudovnjača, katjonski tenzid, sorpcija, anjonski zagađivači, tretman otpadnih voda 